\title{
Acid-responsive properties of fibrils from heat-induced whey protein concentrate
}

\author{
Hong-Hua Xu, ${ }^{1}$ Jing Wang, Shi-Rong Dong, Wen Cheng, Bao-Hua Kong, and Jun-Yan Tan \\ Key Laboratory of Dairy Science, Ministry of Education, Northeast Agricultural University, 150030 Harbin, People's Republic of China
}

\begin{abstract}
The heat-induced fibrils of whey protein concentrate (WPC) have demonstrated an acid-responsive property; that is, the fibrils went through formation-depolymerization-reformation as $\mathrm{pH}$ was adjusted to $1.8,6.5$, and back to 1.8. We investigated the microstructure, driving force, and thermal stability of $3.0 \%$ (wt) WPC nanofibrils adjusted between $\mathrm{pH} 6.5$ and 1.8 twice. The results showed that the nanofibrils had acid-responsive properties and good thermal stability after reheating for $10 \mathrm{~h}$ at $90^{\circ} \mathrm{C}$ and adjusting $\mathrm{pH}$ from 1.8 to 6.5 to 1.8 . The content of WPC fibril aggregates was not much different with the prolongation of heating times during $\mathrm{pH}$ variation. Although the nanofibrils' structure could be destroyed only by changing the $\mathrm{pH}$, the essence of this destruction might only form fiber fragments, polymers that would restore a fibrous structure upon returning to $\mathrm{pH}$ 1.8. A described model for the acid-responsive assembly of fibrils of WPC was proposed. The fibrils went through formation-depolymerization-reformation by weaker noncovalent interactions (surface hydrophobicity) as $\mathrm{pH}$ changed from 1.8 to 6.5 back to 1.8 . However, the fibrils lost the acid-responsive properties because much more S-S (disulfide) formation occurred when the solution was adjusted to $\mathrm{pH} 6.5$ and reheated. Meanwhile, fibrils still possessed acid-responsive properties when reheated at $\mathrm{pH} 1.8$, and the content of fibrils slightly increased with a further reduction of $\alpha$-helix structure.
\end{abstract}

Key words: whey protein concentrate, fibrils, microstructure, acid responsive

\section{INTRODUCTION}

The study of protein aggregation has been important in relation to food production and biotechnology (Bau-

Received December 27, 2015.

Accepted April 28, 2016.

${ }^{1}$ Corresponding author: xhh3161@126.com er et al., 2000). Many globular proteins have shown the ability to form long, thin fibrillar aggregates at $\mathrm{pH} 2.0$ and low ionic strength, such as $\beta-\mathrm{LG}$ (Kavanagh et al., 2000; Ikeda and Morris, 2002; Veerman et al., 2002, 2003), whey protein concentrates (WPC; Wang et al., 2013), and whey protein isolates (WPI; Durand et al., 2002; Gosal et al., 2002; Arnaudov et al., 2003), after heating at high temperature for several hours. Arnaudov et al. (2003) described fibrils of $\beta-L G$ at acidic $\mathrm{pH}$ in 3 main stages: an initial unfolding step, a step of linear fibrillar aggregation via nucleation and growth, and finally a step of random association of the fibrils. Ionic strength and $\mathrm{pH}$ also affect both the kinetics of fibril formation and the morphology of fibrils (Aymard et al., 1999; Bolder et al., 2006; Arnaudov and de Vries, 2007). With heat treatment at $80^{\circ} \mathrm{C}$, added $\mathrm{NaCl}$ substantially accelerated $\beta-\mathrm{LG}$ denaturation at $\mathrm{pH} 2.5$ (Schokker et al., 2000). Flexible fibrillar networks are formed at $\mathrm{pH}$ 3.35 , and more branching is observed with an increase in $\mathrm{CaCl}_{2}$, equating to an increase of ionic strength of $60 \mathrm{~m} M$ (Mudgal et al., 2009). Fibrils become shorter and more flexible and have a lower critical percolation concentration of $\beta$-LG fibril gel with increasing ionic strength (Mudgal et al., 2011). Surface hydrophobicity plays a dominant role in the formation of fibrils aggregates. Except the hydrophobic interactions, other noncovalent interactions such as ionic bonds, van der Waal's force, and hydrogen bonds also stabilize the formation of fibrils, whereas disulfide interchange reactions have been shown to be inhibited at low $\mathrm{pH}$ (McKenzie et al., 1972). Disulfide bonding between $\beta$-LG molecules does not occur to any significant extent because cysteine residues are predominantly protonated (Otte et al., 2000; Alting et al., 2002). The formation of heat-induced nanofibrils is due to noncovalent interactions; therefore, its aggregation properties might be different from normal protein aggregates. The objective of the present study was to investigate the variation of properties between nanofibrils and normal protein aggregates of WPC through adjusting $\mathrm{pH}(\mathrm{pH} 1.8,6.5)$ and reheating $\left(90^{\circ} \mathrm{C}, 10 \mathrm{~h}\right)$. Finally, a described model for the assembly and depolymerization of WPC fibrils was proposed at $\mathrm{pH}$ between 1.8 and 6.5. 


\section{MATERIALS AND METHODS}

\section{Materials}

The WPC-80 (76.93\% protein, $1.4 \%$ fat, $5.6 \%$ lactose, $4.62 \%$ ash) was purchased from Hilmar Cheese Co. (Hilmar, CA). Thioflavin $\mathrm{T}$ and 1-anilino-8 naphthalene sulfonate were purchased from Sigma-Aldrich (St. Louis, MO). 2,2'-Dinitro-5,5'-dithiodibenzoate (DTNB) was purchased from Merck (Darmstadt, Germany). All other reagents and chemicals were of analytical grade. All the reported results were averages of 3 separate experiments.

\section{Solution Preparation}

The WPC powder was dissolved in double-distilled water, and, after dissolving, the solution was adjusted to $\mathrm{pH} 2.0$ by adding $6 \mathrm{M} \mathrm{HCl}$. To remove any undissolved protein, the solution was centrifuged at 19,000 $\times g$ (GL-21M centrifuge, Shanghai Precision Instruments Co. Ltd., Shanghai, China) for $30 \mathrm{~min}$ at $4^{\circ} \mathrm{C}$. The nitrogen content of supernatants were determined by Kjeldahl analysis $(\mathrm{N} \times 6.38$; KDN-102C, Shanghai Qian Jian Instruments Co. Ltd.) and the supernatant was diluted into $3.0 \%$ (wt) solution; to adjust $\mathrm{pH}$ to 1.8 $\left(6 \mathrm{M} \mathrm{HCl}, 0.1 \mathrm{M} \mathrm{HCl}\right.$ ), solutions were heated at $90^{\circ} \mathrm{C}$ for different periods of time $(0,1,2,3,4,5,6,7,8,9$, and $10 \mathrm{~h}$ ) in a water bath. After heat treatment, the samples were immediately cooled to room temperature by immersing in ice bath to form WPC nanofibrils (Ko and Gunasekaran, 2006; Bolder et al., 2007; Akkermans et al., 2008). Normal protein aggregates (pH 6.5) were formed by the same methods, except for adjusting $\mathrm{pH}$ (before centrifuging and heating treatment).

\section{Transmission Electron Microscopy}

The microstructure of heated protein dispersions was investigated by transmission electron microscopy (H7650, Hitachi High-Technologies Corporation, Krefeld, Germany) according to the procedure of Krebs et al. (2009), with some modifications. Protein dispersion was diluted to $0.3 \%$ (wt) in Millipore water (Simplicity Purification System, Millipore, France), and a droplet of the diluted sample was loaded onto an amorphous carbon film supported by a copper grid. After $15 \mathrm{~s}$, the droplet was removed with a filter paper. The samples were studied by transmission electron microscopy (TEM), operating at $80 \mathrm{kV}$.

\section{Turbidity}

The turbidity of dispersions was measured using a UV spectrophotometer (TU-1800, Beijing Precision
Instruments Co. Ltd., Beijing, China) according to the procedure of Kurganov (2002), with some modifications; the path length of sample cell used was $10 \mathrm{~mm}$. The protein samples were diluted to the concentration of $1.5 \%$ (wt) in double-distilled water, vortexed, and had absorbance measured at $400 \mathrm{~nm}$ and room temperature; the double-distilled water was used as the blank and turbidity values were represented through absorbance values. All measurements were performed in triplicate.

\section{Protein Surface Hydrophobicity}

The surface hydrophobicity of the protein samples was determined by the method of Tubio et al. (2004). Protein dispersions were diluted with $0.01 M$ phosphate buffer ( $\mathrm{pH}$ 6.7), containing samples of varying total WPC $(0.02,0.01,0.005$, and $0.0025 \%, \mathrm{wt} / \mathrm{vol})$ added to aliquots $(20 \mu \mathrm{L})$ of 1-anilino- 8 naphthalene sulfonate $(8.0 \mathrm{mmol} / \mathrm{L}$ in the same buffer $)$, vortexed, and kept in the dark for $20 \mathrm{~min}$. The fluorescence emission intensities at $470 \mathrm{~nm}$ (whereas excitement was 390 $\mathrm{nm}$ ) for each protein concentration were measured with fluorescence spectrophotometer (F-4500, Hitachi HighTechnologies Corporation). The initial slope of the plot of fluorescence intensity versus protein concentration, which was calculated by linear regression (in all cases, $\mathrm{R}^{2}>0.95$ ), was used as an index of the surface hydrophobicity of the protein sample evaluated. All measurements were performed in triplicate.

\section{Determination of Free Sulfhydryl Group}

Free sulfhydryl group (SH) contents of protein samples were determined by the method of Shimada and Cheftel (1989), with some modifications. For free sulfhydryl group content determination, $5 \mathrm{~mL}$ of the Tris-Gly buffer $(0.086 M$ Tris, $0.09 M$ glycine, 0.004 $M$ EDTA, pH 8.0) containing $8 M$ urea were added to $0.3-\mathrm{mL}$ protein samples $(30 \mathrm{mg} / \mathrm{mL})$. Then, $20 \mu \mathrm{L}$ of DTNB (Merck) was added and absorbance was measured at $412 \mathrm{~nm}$ with UV spectrophotometer (UV-2401 PC, Shimadzu Corporation, Kyoto, Japan) after 15 min. The supernatants in buffer without DTNB were used as blanks. The calculation was as follows:

$$
\mathrm{SH}(\mu \mathrm{mol} / \mathrm{g})=\frac{\left(73.53 \times A_{412} \times D\right)}{C},
$$

where $A_{412}$ is the absorbance at $412 \mathrm{~nm}, C$ is sample concentration $(\mathrm{mg} / \mathrm{mL}), D$ is the dilution factor, and 73.53 is derived from $10^{6} /\left(1.36 \times 10^{4}\right) ; 1.36 \times 10^{4}$ is the molar absorptivity (Ellman, 1959) and $10^{6}$ is for 
the conversion from a molar basis to a millimolar per milliliter basis and from milligrams to grams of solids.

\section{Aggregate Rate}

The protein dispersions $(3 \%$, wt, protein basis) were heated at $90^{\circ} \mathrm{C}$ for $0,1,2,3,4,5,6,7,8,9$, and 10 $\mathrm{h}$, normal aggregates were heated at $90^{\circ} \mathrm{C}$ at $\mathrm{pH} 6.5$, fibril aggregates were heated at $90^{\circ} \mathrm{C}$ at $\mathrm{pH} 1.8$. Twenty milliliters of each protein solution was transferred to 45-mL centrifuge tubes and then centrifuged at 19,000 $\times g$ for 30 min at $4^{\circ} \mathrm{C}$; the protein concentration of the precipitation was determined by Kjeldahl analysis: $\mathrm{N} \times$ 6.38 (KDN-102C, Shanghai Qian Jian Instruments Co. Ltd.). The calculation was

$$
\text { Aggregate rate }=C_{t} / C_{0},
$$

where $C_{t}$ and $C_{0}$ represent the protein concentration $(\mathrm{mg} / \mathrm{mL})$ after $t$ and $0 \mathrm{~h}$, respectively. All measurements were performed in triplicate.

\section{Thioflavin T Fluorescence}

A thioflavin $\mathrm{T}(\mathbf{T h} \mathbf{T})$ solution $(800 \mathrm{mg} / \mathrm{L})$ was prepared by dissolving ThT in $10 \mathrm{~m} M$ sodium phosphate buffer (pH 7.0) containing $200 \mathrm{mM} \mathrm{NaCl}$ and the solution was filtered $(0.2 \mu \mathrm{m}$, Minisart, Sartorius, Gottingen, Germany) to remove undissolved ThT. The stock solution was stored at $4^{\circ} \mathrm{C}$ in a brown glass bottle covered with aluminum foil. Working solution was prepared by diluting the stock solution 50 fold in phosphate- $\mathrm{NaCl}$ buffer. Samples of $400 \mu \mathrm{L}$ were added to $10 \mathrm{~mL}$ of ThT solution. The fluorescence of the samples was measured on a Hitachi F4500 fluorescence spectrometer (Tokyo, Japan) with excitation at $460 \mathrm{~nm}$ and emission at 490 nm (Akkermans et al., 2008); slit widths were 5 and 10 $\mathrm{nm}$, respectively. All measurements were performed in triplicate.

\section{Circular Dichroism Spectroscopy}

Far-UV circular dichroism spectra were obtained using J-815 spectropolarimeter (Jasco Inc., Easton, MD) in $0.02-\mathrm{cm}$ light path quartz cells by the method of Kurouski et al. (2012) with some modifications. All samples of $100 \mu \mathrm{L}$ were diluted with $2.9 \mathrm{~mL}$ of icecold $0.005 M$ Tris-HCl buffer, $\mathrm{pH} 7.5$, and stored on ice until the circular dichroism measurements the next day; the samples were scanned from 190 to $280 \mathrm{~nm}$ with a scan rate of $100 \mathrm{~nm} / \mathrm{min}$, and CD measurements were expressed as mean residue ellipticity $(\theta)$ in degrees $\mathrm{cm}^{-2} \mathrm{dmol}^{-1}$. Protein $\alpha$-helix was evaluated using the formula of Yang et al. (1986):

$$
\alpha-\operatorname{helix}(\%)=\frac{-\left([\theta]_{222}+3,000\right)}{33,000} .
$$

All measurements were performed in triplicate.

\section{Acid Response}

We used the protein concentration of 3.0\% (wt) WPC nanofibrils with different heating times $(0,1,2,3,4$, $5,6,7,8,9$, and $10 \mathrm{~h}$ ) as control samples. The $3.0 \%$ (wt) WPC nanofibrils were first adjusted to $\mathrm{pH} 6.5$ (1 $M \mathrm{NaOH}, 0.1 M \mathrm{NaOH}$ ), first adjusted back to $\mathrm{pH}$ $1.8(1 \mathrm{M} \mathrm{HCl}, 0.1 \mathrm{M} \mathrm{HCl})$, then reheating the samples adjusted them back to $\mathrm{pH} 1.8$ by the corresponding time $(0,1,2,3,4,5,6,7,8,9$, and $10 \mathrm{~h})$; after reheating, nanofibrils were second adjusted to $\mathrm{pH}$ 6.5 (1 M $\mathrm{NaOH}, 0.1 M \mathrm{NaOH}$ ), second adjusted back to $\mathrm{pH} 1.8$ $(1 \mathrm{M} \mathrm{HCl}, 0.1 \mathrm{M} \mathrm{HCl}$ ), and various indicators (surface hydrophobicity, free sulfhydryl group, aggregate rate, thioflavin $\mathrm{T}$ fluorescence, turbidity) were determined at different stages.

\section{Statistical Analysis}

An ANOVA was conducted using Statistix 8.1 (Systat Software, Chicago, IL) and Microsoft Excel (version 2003, Microsoft Corp., Redmond, WA). Replicate means were considered significantly different at $P<$ 0.05 unless stated. When significant differences were indicated by ANOVA, Tukey pair-wise comparisons were performed to indicate where the differences between properties existed.

\section{RESULTS}

\section{TEM}

The WPC nanofibrils had $\mathrm{pH}$ adjusted between 1.8 and 6.5 twice and the morphology of fibrils aggregation was examined using TEM (Figure 1). Nanofibril solutions were first adjusted to $\mathrm{pH} 6.5$ and the nanofibril structure was destroyed, with fibril fragments aggregating into cluster-structure aggregates (Figure 1b) different from the structure of normal aggregates, which formed a particulate polymer by heating at a $\mathrm{pH}$ of 6.5 (Figure 2). The cluster-structure aggregates could reform fibril-structure aggregates after adjusting $\mathrm{pH}$ from 6.5 to 1.8 again (Figure 1c); the solutions adjusted back to $\mathrm{pH} 1.8$ were reheated for $10 \mathrm{~h}$ and the fibrils also maintained fine-stranded morphology 
(Figure 1d). After the second adjustment of $\mathrm{pH}$, the results were similar to the first treatment except more branches were noted (Figure 1e and f). We found that the nanofibrils had acid-responsive properties and good thermal stability after reheating.

\section{Turbidity}

We noted a gradual development of turbidity at 400 $\mathrm{nm}$, along with acid-responsive processing and reheating (Figure 3). We observed that the optical density values of all samples were increased. A sharp increase of normal WPC aggregates ( $\mathrm{pH}$ 6.5) was observed in the range of $58.53 \%$ at heating for $1 \mathrm{~h}$, then gradually increased at 2 to $10 \mathrm{~h}$, which were increased slowly and only increased by $29.11 \%$ at $10 \mathrm{~h}$. The optical density values of fibril solutions adjusted to $\mathrm{pH} 6.5$ twice were obviously higher than that of nanofibrils, which were similar to normal WPC aggregates. Conversely, the trend for fibril solutions first adjusted to $\mathrm{pH} 1.8$ was the same as the nanofibrils. When the sample first adjusted to $\mathrm{pH} 1.8$ was reheated for $10 \mathrm{~h}$, the optical density values were similar to the initial values of fibrils and the TEM image showed that nanofibrils became thicker, branched, and formed more amyloid structure after reheating (Figure 1d). The optical density values of second change in fibrils back to $\mathrm{pH} 1.8$ were similar to reheating treatment at first adjustment to $\mathrm{pH} 1.8$ and the initial values of fibrils.

\section{Content of Protein Aggregation}

The amount of WPC aggregation was much different with the prolongation of heating times at $2 \mathrm{pH}$ values (Figure 4). The normal WPC ( $\mathrm{pH}$ 6.5) aggregated much faster than that of forming fibrils ( $\mathrm{pH}$ 1.8), which was approximately 6 times faster compared with the amount of nanofibrils after heating for $10 \mathrm{~h}$. It was interesting the content of protein aggregation increased slightly when the fibril solutions were adjusted to $\mathrm{pH}$ 6.5 , and much lower than that of normal aggregates from nature WPC heated at a $\mathrm{pH}$ of 6.5. The results showed that the aggregate structure of the fibril solutions when changing from $\mathrm{pH} 1.8$ to 6.5 was different from reorganization of fibrils because more aggregation occurred. When the solutions changed back to pH 1.8 twice, the values were not changed. From the acid-responsive processing, we suggest that the depolymerization and reformation of fibrils did not lead to the destruction of fibril structure completely or form other aggregation structures. This inference could also be confirmed from the TEM results, as fibril fragments aggregated into cluster-structure aggregation with in- creasing $\mathrm{pH}$ (Figure 1) and fibrils could be reformed by decreasing $\mathrm{pH}$.

\section{ThT}

Recently, it was found that ThT fluorescent molecules could be combined with the $\beta$-sheet structure of fibrils (i.e., measured fluorescence intensity was proportional to the content of fibrils; Groenning et al., 2007). The fluorescence intensity of $\mathrm{pH} 1.8$ nanofibrils was significantly higher than that of normal WPC aggregates (pH 6.5; Figure 5). When the nanofibril solutions were first adjusted to $\mathrm{pH}$ 6.5, the ThT fluorescence intensity showed a $\sim 36 \%$ decrease compared with nanofibrils (1.8), then the values rose again with a change to $\mathrm{pH}$ 1.8. After second adjustment to $\mathrm{pH} 6.5$, the results were similar to the first adjustment without further reduction. We found intermediate values for the nanofibrils solutions that were first or second adjusted to $\mathrm{pH} 6.5$ between that of normal WPC aggregates at $\mathrm{pH} 6.5$ and nanofibrils at $\mathrm{pH} 1.8$. The results showed that the structure of aggregates first or second adjusted to $\mathrm{pH}$ 6.5 were quite different from the normal aggregates at the same $\mathrm{pH}$, although the nanofibril structure could be destroyed only by changing $\mathrm{pH}$ and the essence of this destruction might only form fiber fragment polymers that would restore a fibrous structure by readjusting to $\mathrm{pH}$ 1.8. Interestingly, the amount of fibril aggregates could be increased by $3 \%$ when the solutions were reheated for $10 \mathrm{~h}$ after adjusting back to $\mathrm{pH} 1.8$ (Figure $5)$. The content of nanofibrils slightly increased with a further reduction of $\alpha$-helix structure in WPC after reheating at a $\mathrm{pH}$ of 1.8 (Table 1 ). The ThT results showed that reheating treatment was more beneficial to increase the fibril content.

\section{DISCUSSION}

The fibrils of WPC went through formation-depolymerization-reformation by adjusting $\mathrm{pH}$ from 1.8 to 6.5 and back to 1.8 , and the nanofibril structure was not destroyed thoroughly. This may be due in part to the major forces of protein molecules which were changed in the process of formation-depolymerization-reformation of nanofibrils. Previous studies deemed that surface hydrophobicity was the major force in formation of nanofibrils (Otte et al., 2000; Alting et al., 2002; Wang et al., 2013). No significant variation in surface hydrophobicity was noted in acid-responsive processing (Table 2), whereas the content of thiol groups did not change significantly in acid-responsive processing as $\mathrm{pH}$ changed from 1.8 to 6.5 to 1.8 . But, compared with the preheating, the reheating treatment could lead to 

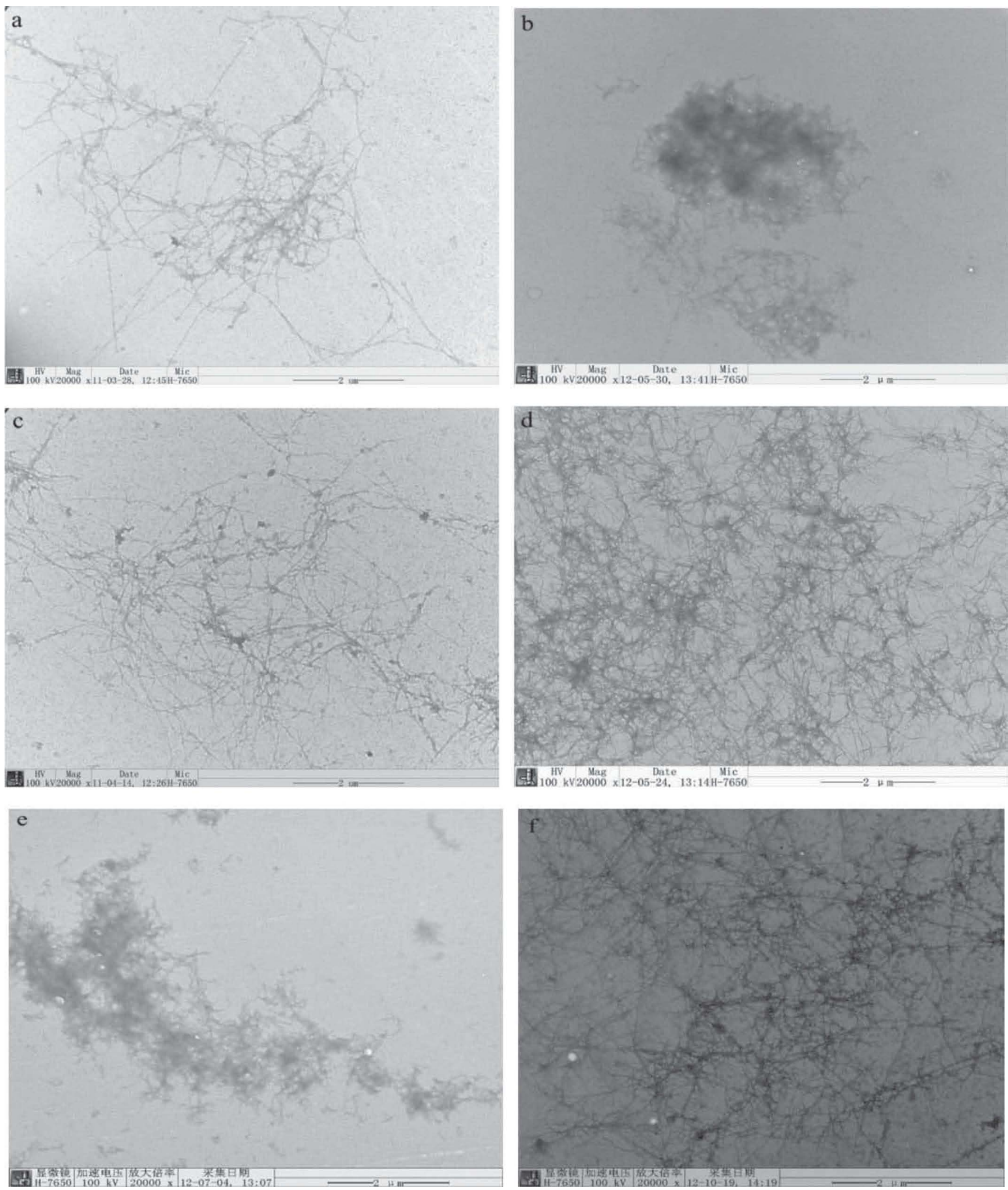

Figure 1. Transmission electron micrographs (TEM) of the $3.0 \%$ (wt) whey protein concentrate nanofibrils at different pH and reheating treatment: (a) $\mathrm{pH} 1.8$, (b) first adjusted to $\mathrm{pH} 6.5$, (c) first changed back to $\mathrm{pH} 1.8$, (d) reheating $\mathrm{pH} 1.8$, (e) second adjusted to $\mathrm{pH} 6.5$, and (f) second changed back to $\mathrm{pH} 1.8$. 

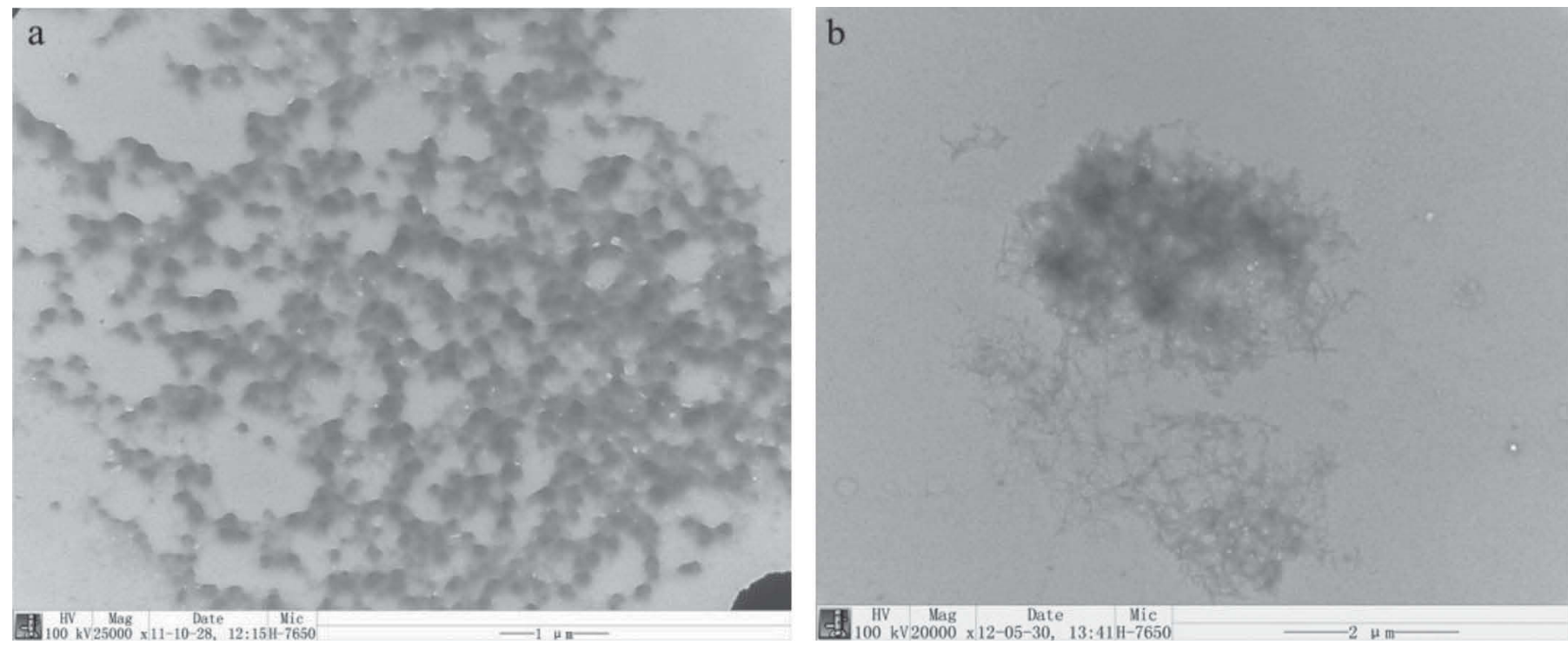

Figure 2. Transmission electron micrographs (TEM) of the 3.0\% (wt) whey protein concentrate (WPC) particulate aggregates and $3.0 \%$ (wt) WPC nanofibrils adjusted to $\mathrm{pH}$ 6.5. The samples ( $\mathrm{pH}$ 6.5) were particulate aggregates (a) and nanofibrils adjusted to $\mathrm{pH} 6.5$ (b; same micrograph as in panel b in Figure 1).

the reduction of surface hydrophobicity $(\sim 19.7 \%)$ and thiol groups $(\sim 23.31 \%)$ as the solutions of first changed back to $\mathrm{pH} 1.8$ after reheating for $10 \mathrm{~h}$. The reduction of thiol groups came from reheating to form disulfide bonds, which were still reformed fibrils at the second

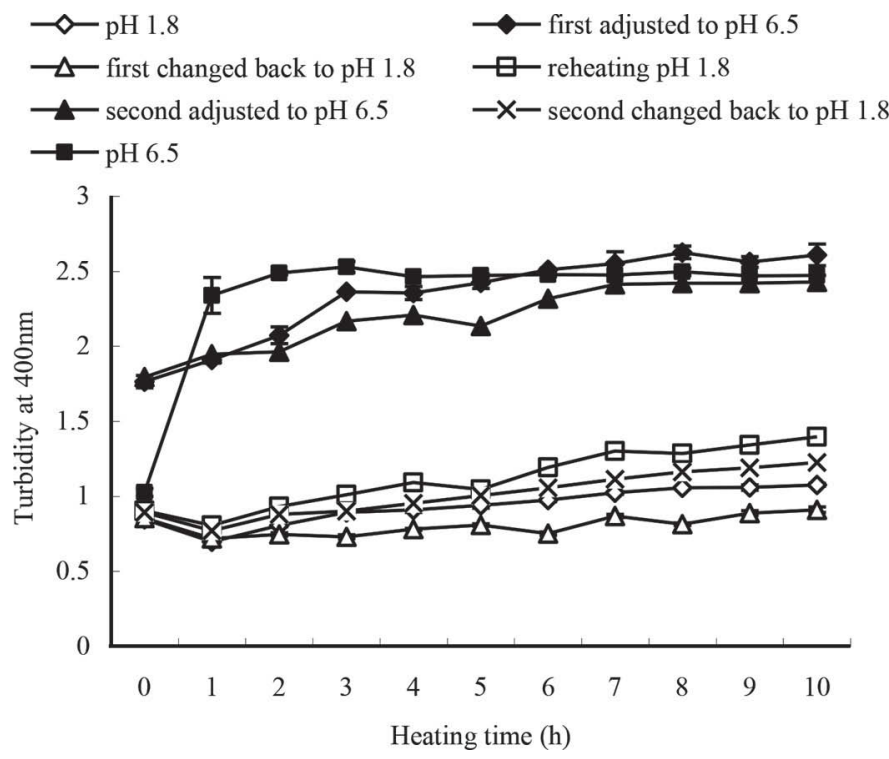

Figure 3. Variation of optical density at $400 \mathrm{~nm}$ for $3.0 \%$ (wt) whey protein concentrate (WPC) nanofbrils at different $\mathrm{pH}$ and reheating treatment. The samples (3\%, wt, protein basis) were particulate aggregates $(\mathrm{pH} 6.5)$, nanofibrils $(\mathrm{pH} 1.8)$, first adjusted to $\mathrm{pH} 6.5$, first changed back to $\mathrm{pH} 1.8$, reheating changed back to $\mathrm{pH} 1.8$ for 10 $\mathrm{h}$ at $90^{\circ} \mathrm{C}$, second adjusted to $\mathrm{pH} 6.5$, and second changed back to $\mathrm{pH}$ 1.8. Data are expressed as the mean $\pm \mathrm{SD}$ of 3 replicates.
$\mathrm{pH}$ adjustment, without affecting acid-responsive properties of nanofibrils. Nevertheless, when $\mathrm{pH}$ changed from 1.8 to 6.5 after heating for $30 \mathrm{~min}$, the reduction of thiol groups showed a $\sim 56.39 \%$ decrease compared
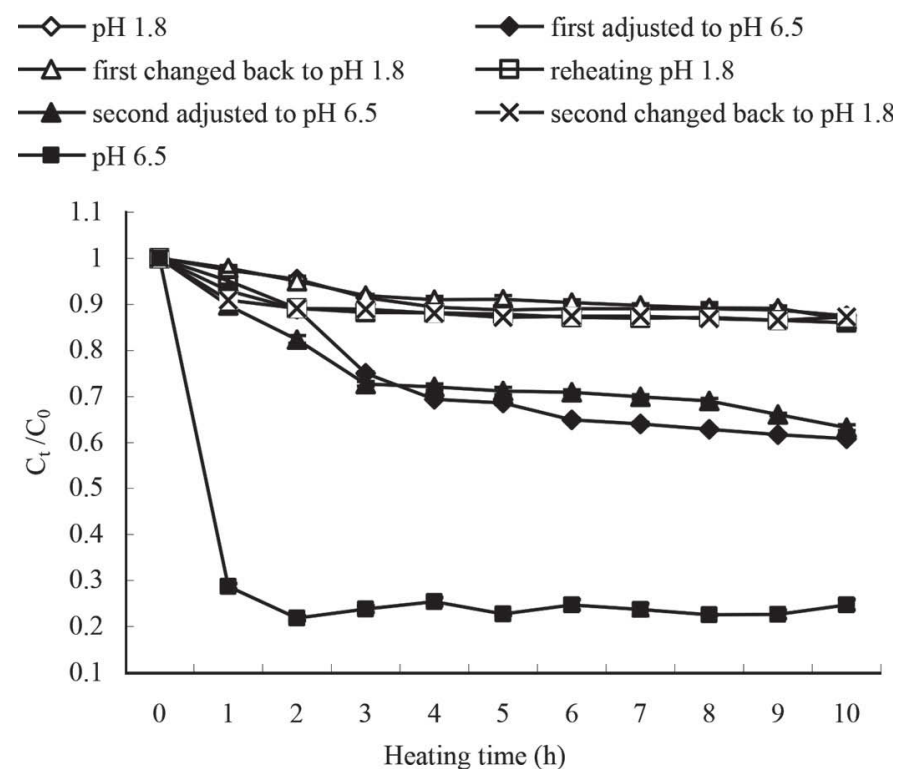

Figure 4. Fractional concentration of nonaggregated whey protein concentrate (WPC) by heating 3\% (wt, protein basis) WPC solution versus heating time at $90^{\circ} \mathrm{C}$ with different $\mathrm{pH}$ and reheating treatment; $\mathrm{C}_{\mathrm{t}} / \mathrm{C}_{0}$ is the ratio of whey protein concentration at time $\mathrm{t}$ and time zero. Reaction conditions: The samples (3\%, wt, protein basis) were particulate aggregates $(\mathrm{pH} 6.5)$, nanofibrils $(\mathrm{pH} 1.8)$, first adjusted to $\mathrm{pH}$ 6.5, first changed back to $\mathrm{pH} 1.8$, reheating changed back to $\mathrm{pH}$ 1.8 for $10 \mathrm{~h}$ at $90^{\circ} \mathrm{C}$, second adjusted to $\mathrm{pH} 6.5$, and second changed back to $\mathrm{pH}$ 1.8. Data are expressed as the mean $\pm \mathrm{SD}$ of 3 replicates. 
Table 1. Variation of $\alpha$-helix of 3.0\% (wt) whey protein concentrate (WPC) dispersions at $0 \mathrm{~h}, 3.0 \%$ (wt) WPC fibril dispersions $(10 \mathrm{~h}$ ), and $3.0 \%$ (wt) WPC nanofibril dispersions after reheating for $10 \mathrm{~h}$

\begin{tabular}{lccc}
\hline Conditions & WPC material & Nanofibrils & Reheating nanofibrils \\
\hline$\alpha$-Helix (\%) & $69.1 \pm 0.34$ & $34.7 \pm 0.56$ & $28.9 \pm 0.72$ \\
\hline
\end{tabular}

with preheating, which led to complete destruction of the fibrils structure and fibrils never reforming.

Based on the results, we developed a new model of acid-responsive aggregation, described in Figure 6. Fibril solution was adjusted to $\mathrm{pH} 6.5$, fibril fragments aggregated into large polymers through weaker noncovalent interactions (surface hydrophobicity), intermolecular repulsion strengthened because of increased surface charges when the $\mathrm{pH}$ was changed back to 1.8 , and large polymers of noncovalent dissociated and led to the reformation of fibrils; however, this dissociation was not complete, which led to fibrils with a more branched and amyloid structure. Conversely, when the solutions were adjusted to $\mathrm{pH} 6.5$ and reheated, the acid-responsive properties were lost because of much more covalent bond (disulfide bond) formation. The content of disulfide bonds in solutions adjusted to $\mathrm{pH}$ 6.5 and reheated for 30 min increased to $54.35 \%$ accompanied by the aggregation of fibril fragments, whereas $\mathrm{pH} 1.8$ solutions increased only approximately $10.58 \%$ after reheating (Table 3). The aggregations from reheating at a $\mathrm{pH}$ of 6.5 were not depolymerized when the conditions changed back to $\mathrm{pH} 1.8$; thus, we could not reform fibril structure. However, reheating the $\mathrm{pH}$ 1.8 fibril solution led to the formation of few disulfide bonds, which was not affected by the acid-responsive properties and could reform fibrils in the processing of $\mathrm{pH}$ adjusted between 6.5 and 1.8 .

\section{CONCLUSIONS}

The WPC nanofibrils showed good acid-responsive properties when adjusting $\mathrm{pH}$ between 6.5 and 1.8 twice. The acid-responsive properties were due to protein molecules aggregating with each other by noncovalent bonds (surface hydrophobicity) into fibrils, which led to the variation of $\mathrm{pH}$ causing fibril formation-

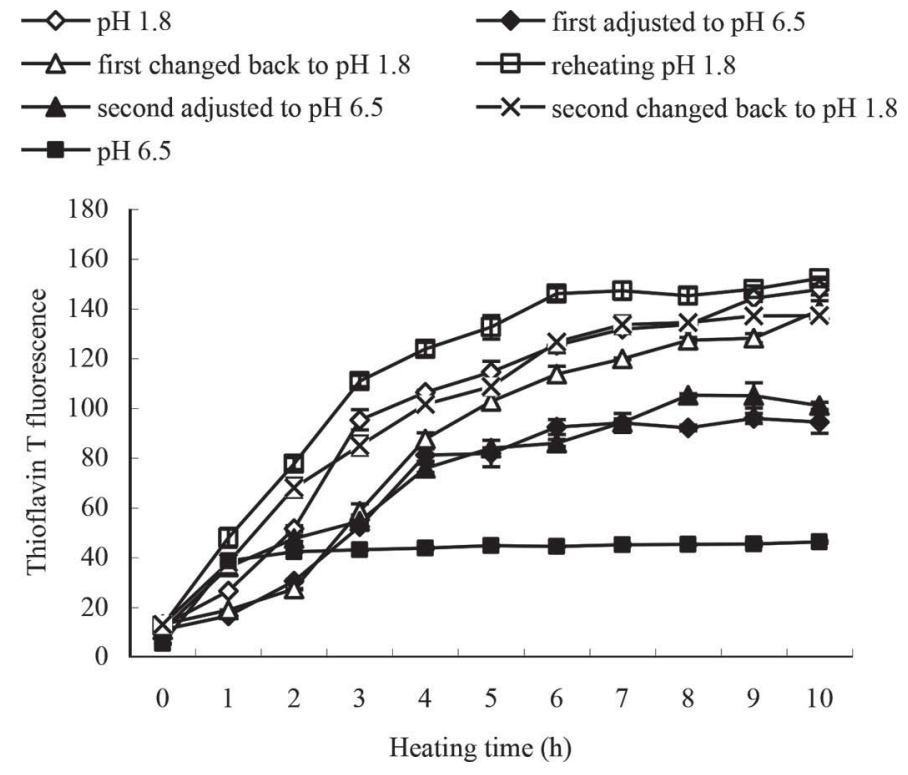

Figure 5. Variation of thioflavin T (ThT) assay of 3.0\% (wt) whey protein concentrate (WPC) nanofbrils at different $\mathrm{pH}$ and reheating treatment. The samples (3\%, wt, protein basis) were particulate aggregates ( $\mathrm{pH} 6.5$ ), nanofibrils ( $\mathrm{pH} 1.8$ ), first adjusted to $\mathrm{pH} 6.5$, first changed back to $\mathrm{pH} 1.8$, reheating changed back to $\mathrm{pH} 1.8$ for $10 \mathrm{~h}$ at $90^{\circ} \mathrm{C}$, second adjusted to $\mathrm{pH} 6.5$, and second changed back to $\mathrm{pH} 1.8$. Data are expressed as the mean \pm SD of 3 replicates.

depolymerization-reformation. A model acid-responsive aggregation pathway was proposed as fibril fragments aggregated into large polymers through weaker noncovalent interactions (surface hydrophobicity) when $\mathrm{pH}$ was adjusted to 6.5 ; large polymers dissociated because of the strengthening of intermolecular repulsion led to reformation of fibrils when $\mathrm{pH}$ was adjusted back to 1.8 . In contrast, solutions adjusted to $\mathrm{pH} 6.5$ after reheating could not reform fibril structure because of many covalent bonds (disulfide bonds) formed between protein molecules. The content of nanofibrils slightly increased with the further reduction of $\alpha$-helix structure in WPC after reheating at a $\mathrm{pH}$ of 1.8 .

\section{ACKNOWLEDGMENTS}

This work was supported by the National Natural Science Foundation of China (No. 31471682, Beijing).

Table 2. Changes in properties of whey protein concentrate nanofibrils $\left(3.0 \%\right.$, wt, heating $10 \mathrm{~h}$ at $\left.90^{\circ} \mathrm{C}\right)$ versus acid-responsive properties at $\mathrm{pH} 1.8$

\begin{tabular}{lcc}
\hline Sample & Free sulfhydryl group $(\mu \mathrm{moL} / \mathrm{g})$ & Surface hydrophobicity \\
\hline pH 1.8 (nanofibrils) & $16,596.66 \pm 9.875^{\mathrm{a}}$ & $90.41 \pm 2.233^{\mathrm{a}}$ \\
Nanofibrils first changed back to pH 1.8 & $15,707.17 \pm 30.158^{\mathrm{b}}$ & $86.17 \pm 0.424^{\mathrm{b}}$ \\
Reheating to pH $1.8\left(10 \mathrm{~h}, 90^{\circ} \mathrm{C}\right)$ & $12,045.32 \pm 13.610^{\mathrm{c}}$ & $68.97 \pm 1.733^{\mathrm{c}}$ \\
Nanofibrils second changed back to pH 1.8 & $11,145.12 \pm 10.520^{\mathrm{d}}$ & $64.86 \pm 1.658^{\mathrm{d}}$ \\
\hline
\end{tabular}

${ }^{\mathrm{a}-\mathrm{d}}$ Different superscripts indicate significant difference at $P<0.05$. 

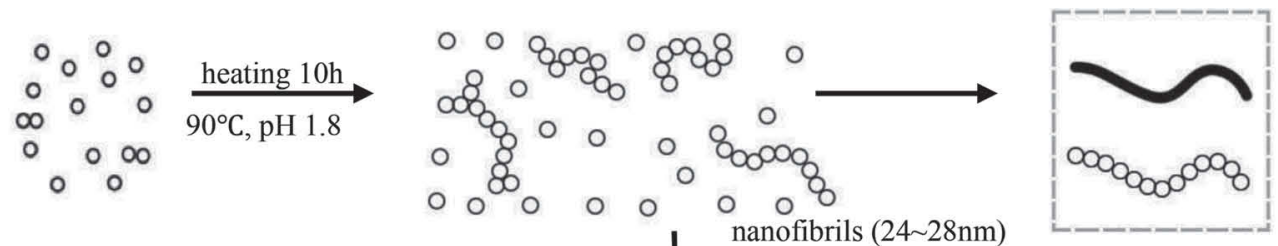

weaker non-covalent bonds

interactions
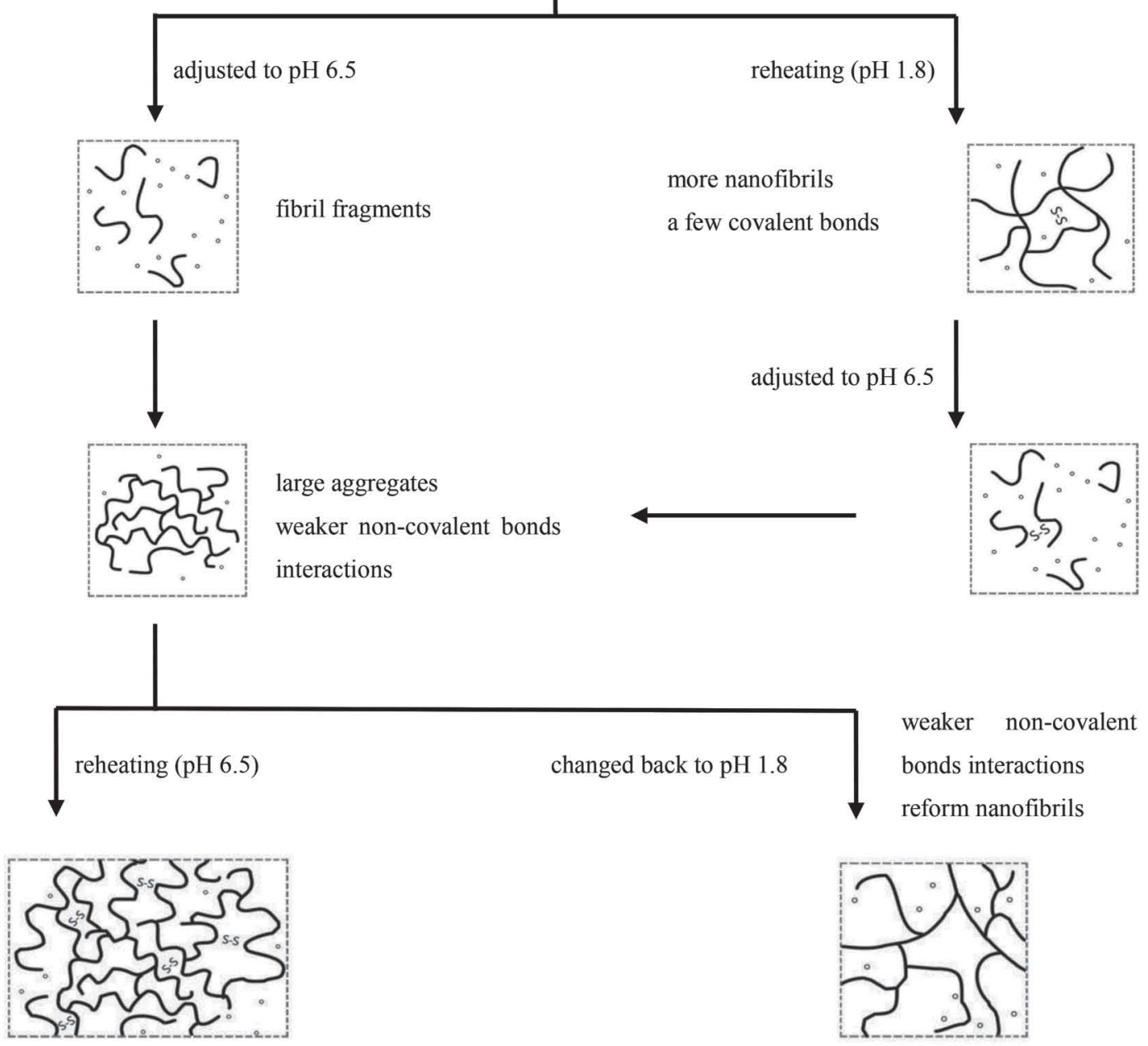

large aggregates

nanofibrils

stronger covalent bonds interactions

unable to reform nanofibrils

Figure 6. Proposed model of nanofibrils acid responsive pathway.

Table 3. Changes in properties of whey protein concentrate nanofibrils $\left(3.0 \%\right.$, wt, heating $10 \mathrm{~h}$ at $\left.90^{\circ} \mathrm{C}\right)$ versus acid-responsive properties at $\mathrm{pH} 6.5$

\begin{tabular}{lcc}
\hline Sample & Turbidity & Free sulfhydryl group $(\mu \mathrm{moL} / \mathrm{g})$ \\
\hline pH 1.8 (nanofibril) & $0.956 \pm 0.027^{\mathrm{d}}$ & $16,596.66 \pm 9.875^{\mathrm{a}}$ \\
Nanofibrils adjusted to pH 6.5 & $2.155 \pm 0.126^{\mathrm{c}}$ & $15,856.77 \pm 10.543^{\mathrm{b}}$ \\
Reheating adjusted to pH $6.5\left(30\right.$ min, $\left.90^{\circ} \mathrm{C}\right)$ & $2.788 \pm 0.214^{\mathrm{a}}$ & $7,238.26 \pm 15.365^{\mathrm{c}}$ \\
Changed back to pH 1.8 & $2.534 \pm 0.137^{\mathrm{b}}$ & $7,135.43 \pm 11.987^{\mathrm{d}}$ \\
\hline a-d Different superscripts indicate significant difference at $P<0.05$.
\end{tabular}




\section{REFERENCES}

Akkermans, C., P. Venema, A. J. van der Goot, H. Gruppen, E. J. Bakx, R. M. Boom, and E. van der Linden. 2008. Peptides are building blocks of heat-induced fibrillar protein aggregates of B-lactoglobulin formed at $\mathrm{pH} 2$. Biomacromolecules 9:1474-1479.

Akkermans, C., A. J. van der Goot, P. Venema, E. van de Linden, and R. M. Boom. 2008. Formation of fibrillar whey protein aggregates: Influence of heat and shear treatment, and resulting rheology. Food Hydrocoll. 22:1315-1325.

Alting, A. C., H. H. J. de Jongh, R. W. Visschers, and J. W. F. A Simons. 2002. Physical and chemical interactions in cold gelation of food proteins. J. Agric. Food Chem. 50:4682-4689.

Arnaudov, L. N., and R. de Vries. 2007. Theoretical modeling of the kinetics of fibrillar aggregation of bovine $\beta$-lactoglobulin at $\mathrm{pH} 2$. J. Chem. Phys. 126:145106

Arnaudov, L. N., R. de Vries, H. Ippel, and C. P. van Mierlo. 2003 Multiple steps during the formation of $\beta$-lactoglobulin fibrils. Biomacromolecules 4:1614-1622.

Aymard, P., T. Nicolai, D. Durand, and A. Clark. 1999. Static and dynamic scattering of $\beta$-lactoglobulin aggregates formed after heatinduced denaturation at $\mathrm{pH}$ 2. Macromolecules 32:2542-2552.

Bauer, R., R. Carrotta, C. Roschel, and L. Ogendal. 2000. Characterization and isolation of intermediates in $\beta$-lactoglobulin heat aggregation at high pH. Biophys. J. 79:1030-1038.

Bolder, S. G., H. Hendrickx, L. M. C. Sagis, and E. van der Linden. 2006. Ca2+-induced cold-set gelation of whey protein isolate fibrils. Appl. Rheol. 16:258-264.

Bolder, S. G., A. Vasbinder, L. M. C. Sagis, and E. van de Linden. 2007. Heat-induced whey protein isolate fibrils: Conversion, hydrolysis, and disulphide bond formation. Int. Dairy J. 17:846-853.

Durand, D., J. C. Gimel, and T. Nicolai. 2002. Aggregation, gelation and phase separation of heat denatured globular proteins. Physica A 304:253-265.

Ellman, G. L. 1959. Tissue sulfhydryl groups. Arch. Biochem. Biophys. $82: 70-77$.

Gosal, W., A. Clark, P. Pudney, and S. Ross-Murphy. 2002. Novel amyloid fibrillar networks derived from a globular protein: Betalactoglobulin. Langmuir 18:7174-7181.

Groenning, M., L. Olsen, M. van de Weert, J. M. Flink, S. Frokjaer, and F. S. Jørgensen. 2007. Study on the binding of Thioflavin $\mathrm{T}$ to beta-sheet-rich and non-beta-sheet cavities. J. Struct. Biol. 158:358-369

Ikeda, S., and V. J. Morris. 2002. Fine-stranded and particulate aggregates of heat-denatured whey proteins visualized by atomic force microscopy. Biomacromolecules 3:382-389.

Kavanagh, G. M., A. H. Clark, and S. B. Ross-Murphy. 2000. Heatinduced gelation of globular proteins: Part 3. Molecular studies on low pH $\beta$-lactoglobulin gels. Int. J. Biol. Macromol. 28:41-50.
Ko, S., and S. Gunasekaran. 2006. Preparation of sub-100-nm b-lactoglobulin (BLG) nanoparticles. J. Microencapsul. 23:887-898.

Krebs, M. R. H., G. L. Devlin, and A. M. Donald. 2009. Amyloid fibril-like structure underlies the aggregate structure across the $\mathrm{pH}$ range for $\beta$-lactoglobulin. Biophys. J. 96:5013-5019.

Kurganov, B. I. 2002. Quantitative estimation of the chaperone-like activity in test-systems based on suppression of protein aggregation. Biochemistry 67:409-422.

Kurouski, D., H. Luo, V. Sereda, F. T. Robb, and I. K. Lednev. 2012 Rapid degradation kinetics of amyloid fibrils under mild conditions by an archaeal chaperonin. Biochem. Biophys. Res. Commun. 422:97-102

McKenzie, H. A., G. B. Ralston, and D. C. Shaw. 1972. Location of sulfhydryl and disulfide groups in bovine-lactoglobulins and effects of urea. Biochemistry 11:4539-4547.

Mudgal, P., C. R. Daubert, and E. A. Foegeding. 2009. Cold-set thickening mechanism of $\beta$-lactoglobulin at low $\mathrm{pH}$ : Concentration effects. Food Hydrocoll. 23:1762-1770.

Mudgal, P., C. R. Daubert, and E. A. Foegeding. 2011. Effects of protein concentration and $\mathrm{CaCl}_{2}$ on cold-set thickening mechanism of $\beta$-lactoglobulin at low pH. Int. Dairy J. 21:319-326.

Otte, J., M. Zakora, and K. B. Qvist. 2000. Involvement of disulfide bands in bovine beta-lactoglobulin B gels set thermally at various pH. J. Food Sci. 65:384-389.

Schokker, E. P., H. Singh, D. N. Pinder, and L. K. Creamer. 2000. Heatinduced aggregation $\beta$-lactoglobulin $\mathrm{AB}$ at $\mathrm{pH} 2.5$ as influenced by ionic strength and protein concentration. Int. Dairy J. 10:233-240.

Shimada, K., and J. C. Cheftel. 1989. Sulfhydryl group/disulfide bond interchange reactions during heat-induced gelation of whey protein isolate. J. Agric. Food Chem. 37:161-168.

Tubio, G., B. Nerli, and G. Picó. 2004. Relationship between the protein surface hydrophobicity and its partitioning behaviour in aqueous two-phase systems of polyethyleneglycol-dextran. J. Chromatogr. B Anaylt. Technol. Biomed. Life Sci. 799:293-301.

Veerman, C., H. Baptist, L. M. Sagis, and E. van der Linden. 2003. A new multistep Ca2+-induced cold gelation process for $\beta$-lactoglobulin. J. Agric. Food Chem. 51:3880-3885.

Veerman, C., H. Ruis, L. M. C. Sagis, and E. van der Linden. 2002. Effect of electro-static interactions on the percolation concentration of fibrillar $\beta$-lactoglobulin gels. Biomacromolecules 3:869-873.

Wang, J., H. H. Xu, and Y. Xu. 2013. Nanofibril formation of whey protein concentrate and their properties of fibril dispersions. Adv Mat. Res. 634:1268-1273.

Yang, J. T., C. S. C. Wu, and H. M. Martinez. 1986. Calculation of protein conformation from circular dichroism. Methods Enzymol. 130:208-269. 